\title{
The Accumulation of \\ Extracellular Macromolecules by Staphylococcus aureus Grown in the Presence of Sodium Chloride and Glucose
}

\author{
By R. E. CRIPPS* AND ELIZABETH WORK \\ Twyford Laboratories Ltd., Twyford Abbey Road, London, N.W. Io \\ (Accepted for publication 21 April 1967)
}

\begin{abstract}
SUMMARY
When grown in broth cultures containing sodium chloride and glucose, Staphylococcus aureus JHM produced protein, RNA and DNA in the culture fluid. Maximum yields were obtained with about $4 \%$ (w/v) sodium chloride and $0.1 \%(\mathrm{w} / \mathrm{v})$ glucose. Accumulation of macromolecules began at the end of exponential growth and was accompanied by a decrease in culture turbidity. Electron microscopy revealed considerable cellular lysis, arising from rupture of newly formed septa. Before lysis occurred, the cocci exhibited many morphological abnormalities. After incubation for about $15 \mathrm{hr}$ the culture showed evidence of fresh growth and the resulting cocci were characterized by abormally thick and uneven walls.

The results suggest that there was interference with the regulation of cellwall synthesis, perhaps due to loss of mesosomes, which were never seen in the cytoplasm of organisms grown in sodium chloride glucose broth.
\end{abstract}

\section{INTRODUCTION}

Cultures of Staphylococcus aureus have been shown to produce both extracellular deoxyribonucleic acid (DNA) (Catlin \& Cunningham, 1958) and an extracellular deoxyribonuclease (Micrococcal Nuclease, EC 3. I . 4.7; Cunningham, Catlin \& Privat de Garilhe, 1956). Accumulation of extracellular DNA occurred only under conditions where the nuclease was inactivated, this being achieved by adding sodium chloride to the culture medium. The nuclease has also been reported to be active against ribonucleic acid (RNA) (Reddi, I96I; Anfinsen, Taniuchi, Heins \& Suriano, 1965). Catlin \& Cunningham (1958) described extracellular DNA mainly as a slime-layer, obtainable by treatment of the sedimented organisms with detergent, but found that a DNA-containing precipitate was produced by adding ethanol to the culture supernatant fluid. The slime-layer DNA fraction was designated extracellular-I and the DNA fraction which was free in the culture supernatant fluid was designated extracellular-2.

The present work was undertaken to investigate further the time course and mechanism of excretion of DNA and other macromolecules by the strain JHM of Staphylococcus aureus. The fractions, prepared as described by Catlin \& Cunningham (1958), were found to contain RNA and protein, in addition to DNA. Electron microscopy of cocci grown in sodium chloride + glucose broth showed gross morphological abnormalities which might provide a clue to the mechanism of so-called 'excretion'.

\footnotetext{
* Present address: 'Shell' Research Ltd., Sittingbourne, Kent.
} 


\section{METHODS}

Organism. Staphylococcus aureus strain JHM was obtained from Dr P. J. White: it originated from the laboratory of the late Professor D. D. Woods. Stock cultures were maintained on nutrient agar slopes, stored at $2^{\circ}$ and subcultured monthly.

Culture medium. The organism was grown in Oxoid nutrient broth No. 2, which contains $0.5 \%(\mathrm{w} / \mathrm{v})$ sodium chloride, with glucose and extra sodium chloride added as indicated. Media were inoculated with organisms grown for $17 \mathrm{hr}$ in nutrient broth No. 2 without any addition. Cultures were grown at $37^{\circ}$ in $25 \mathrm{ml}$. or $250 \mathrm{ml}$. media in $250 \mathrm{ml}$. or 21 . vessels, respectively, being shaken on a gyro-rotary shaker.

Extraction of extracellular- 1 and extracellular-2 fractions. Organisms were harvested by centrifugation and resuspended in $4 \%(\mathrm{w} / \mathrm{v})$ aqueous $\mathrm{NaCl}$ solution. To obtain the extracellular-I fraction, sodium dodecylsulphate was added to the coccal suspension to a concentration of $0.25 \%(\mathrm{w} / \mathrm{v})$. The mixture was then stirred at room temperature for $3 \mathrm{hr}$, centrifuged, and the cell pellet discarded. The supernatant solution was cooled in ice and two volumes of industrial ethanol at $2^{\circ}$ added. The resulting fibrous precipitate was recovered by centrifugation and dissolved in distilled water. The extracellular-2 fraction was obtained by addition of 2 volumes of industrial ethanol to the original culture supernatant fiuid, before addition of dodecyl sulphate, both liquids being at $2^{\circ}$. The precipitate was collected by centrifugation and dissolved in distilled water. The two fractions were analysed without further purification. When nutrient broth itself was treated with ethanol, a precipitate was produced, which, on analysis, gave positive results for DNA, RNA and protein, and presumably consisted of ethanol-insoluble oligonucleotides and peptides. The amounts of precipitable materials varied from batch to batch, and were corrected for where indicated.

Analytical methods. DNA was determined by the method of Burton (1956), protein by the method of Lowry, Rosebrough, Farr \& Randall (195I) and RNA by the orcinol method as described by Morse \& Carter (1949). Aqueous solutions of highly polymerized calf thymus DNA and yeast RNA (from The British Drug Houses Ltd., Poole, England) and ovalbumin (from Koch-Light Laboratories Ltd., Colnbrook, Buckinghamshire), were used as references in the chemical analyses. No correction was made for the participation of DNA in the RNA estimation since the amount of RNA present in the fractions was always much greater than that of DNA. The activity of the extracellular deoxyribonuclease (EC 3.I.4.7) in the extracellular-2 fraction was determined as described by Alexander, Heppel \& Hurwitz (I96I) except that the glycine buffer used was at $\mathrm{pH}$ 10.0.

Cell walls. Cell walls were prepared and analysed as described by Allsop \& Work (1963) with the additional step of heating the capsule for $15 \mathrm{~min}$. at $60^{\circ}$ immediately after breaking the organisms.

Optical measurements. Extinctions were determined in SP 500 or SP 600 Unicam spectrophotometers. The turbidity of cultures diluted $\mathrm{I} / 5$ with water was determined by measuring the extinction at $600 \mathrm{~m} \mu$, only slightly higher values being obtained when the culture was diluted with sodium chloride solutions of the same concentration as in the culture medium.

Electron microscopy. Organisms to be studied with the electron microscope were fixed by centrifugation from the culture in the presence of $2 \%(\mathrm{v} / \mathrm{v})$ glutaraldehyde, washed for $30 \mathrm{~min}$. in $0.1 \mathrm{M}$-phosphate buffer ( $\mathrm{pH} 7$ ), and finally fixed overnight in 
$\mathrm{I} \%(\mathrm{w} / \mathrm{v})$ osmium tetroxide in $0.1 \mathrm{I}$-phosphate buffer $(\mathrm{pH} 7)$. Samples were dehydrated and embedded in Epon 8I2 as described by Luft (196I). Ultrathin sections were cut with a Huxley Microtome and were stained with lanthanum nitrate and, sometimes, lead citrate. Specimens were examined with a Philips 100 electron microscope working at $60 \mathrm{kV}$.

\section{RESULTS}

\section{Relative amounts of extracellular-I and extracellular-2 fractions}

Staphylococcus aureus JHM was grown for $48 \mathrm{hr}$ in nutrient broth No. 2 to which I $\%(\mathrm{w} / \mathrm{v})$ glucose $+4 \%(\mathrm{w} / \mathrm{v}) \mathrm{NaCl}$ had been added (total $\mathrm{NaCl}$ concentration $4.5 \%$ $\mathrm{w} / \mathrm{v}$ ), and the compositions of the two extracellular fractions were compared (Table I). Both fractions contained DNA, RNA and protein, DNA being in the lowest concentration. The amount of materials free in the culture supernatant fluid was at least Io times greater than that attached to the cocci. It would appear that in this strain, the slime-layer, if one exists in the accepted sense, contributed relatively little to the total extracellular material. In all subsequent experiments, macromolecules were estimated only in the extracellular-2 fraction.

Table I. Amounts of DNA, RNA and protein in the extracellular fractions from a culture of Staphylococcus aureus strain IHM $_{\mathrm{grown}}$ for $48 \mathrm{hr}$ in nutrient broth No. $2+\mathrm{I} \%(\mathrm{w} / \mathrm{v})$ glucose $+4 \%(w / v) ~ N a C l$

\begin{tabular}{|c|c|c|c|}
\hline & DNA & $\begin{array}{l}\text { RNA } \\
\text { cultur }\end{array}$ & Protein \\
\hline $\begin{array}{l}\text { Extracellular I } \\
\text { Extracellular 2* }\end{array}$ & $\begin{array}{r}5.4 \\
42 \cdot 4\end{array}$ & $22 \cdot 2$ & $17 \cdot 4$ \\
\hline
\end{tabular}

* Corrected for the amounts of reacting materials precipitated from broth before inoculation.

\section{Effect of sodium chloride and glucose on accumulation of macromolecules in cultures}

Organisms were grown for $24 \mathrm{hr}$ in nutrient broth containing I \% (w/v) glucose and different concentrations $(0.5$ to $6.5 \%, \mathrm{w} / \mathrm{v})$ of $\mathrm{NaCl}$. Immediately before removing the organisms, solid $\mathrm{NACl}$ was added to the cultures to bring the concentration in all flasks to $6.5 \%(\mathrm{w} / \mathrm{v})$. Extracellular-2 fractions were then prepared from the culture supernatant fluids and analysed. The results (Fig. I) indicated that, for all three macromolecules, maximum extracellular accumulation occurred at $2.5-4.5 \%(\mathrm{w} / \mathrm{v})$ $\mathrm{NaCl}$. In the absence of added $\mathrm{NaCl}$, the concentrations of nucleic acids were very low, but a sharp increase occurred when the $\mathrm{NaCl}$ concentration was increased to $2.5 \%$ (w/v). A marked decrease in extracellular nucleic acids was noted on increasing the $\mathrm{NaCl}$ concentration from $4.5 \%$ to $6.5 \%(\mathrm{w} / \mathrm{v})$. Protein accumulation showed a similar $\mathrm{NaCl}$ dependence, but the concentration with no added $\mathrm{NaCl}$ was considerably higher than the nucleic acid concentrations. After incubation for $24 \mathrm{hr}$, the protein concentration was greater than the RNA concentration, but, on prolonged incubation, loss of protein occurred and at $48 \mathrm{hr}$ less protein than RNA was present.

The effect of glucose concentration on accumulation was investigated by growing the organisms for $48 \mathrm{hr}$ in nutrient broth containing $4.5 \% \mathrm{NaCl}$ to which sterile glucose 
was added to give various final concentrations $(0-0.3 \%, w / v)$. Analysis of the extracellular-2 fractions showed (Fig. 2) that accumulation of all three macromolecules in the culture increased with increasing glucose concentrations up to $0.1 \%(w / v)$, after which the concentrations stayed essentially constant. Some accumulation occurred even in the absence of glucose. Increasing glucose concentrations had less effect on DNA accumulation than on RNA or protein.

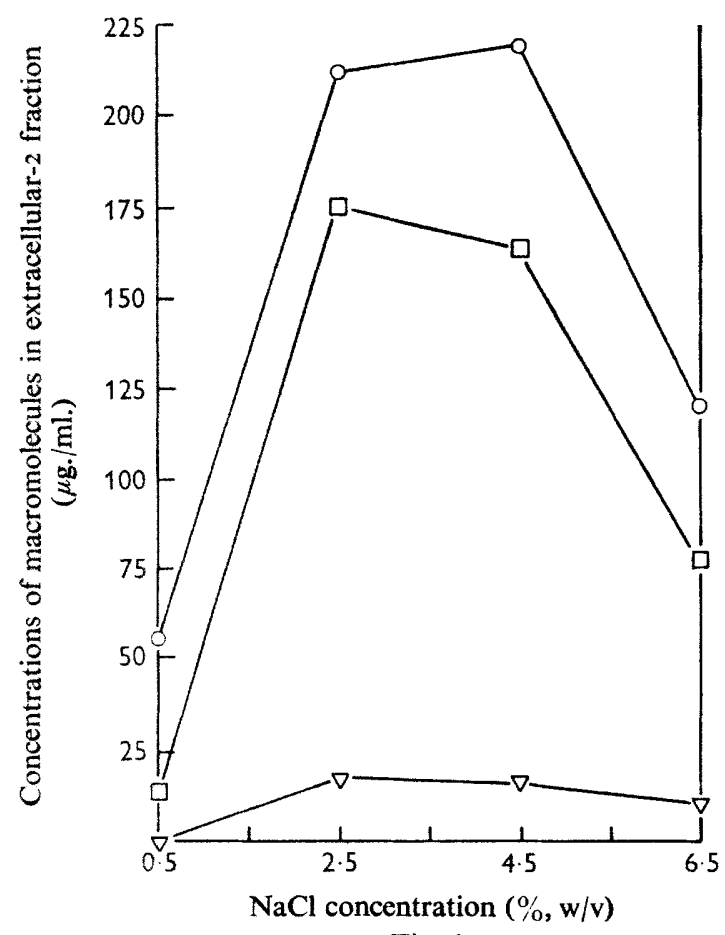

Fig. 1

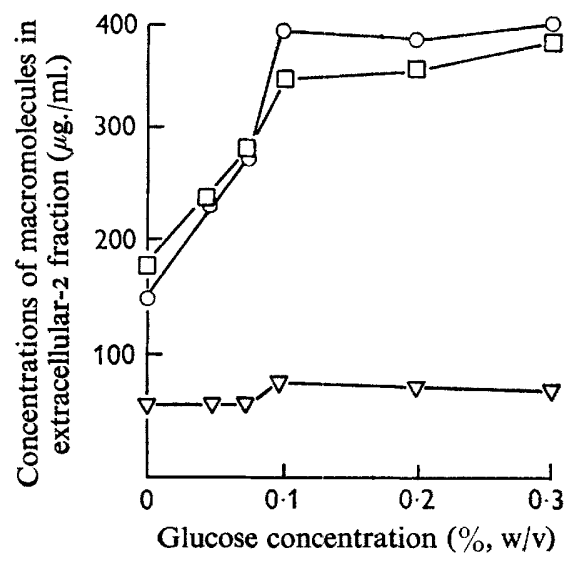

Fig. 2

Fig. 1. The effect of $\mathrm{NaCl}$ concentration in the culture medium on the concentrations of DNA $(\nabla-\nabla)$, RNA $(\square-\square)$ and protein $(O-O)$ found in the extracellular-2 fraction after incubation for $24 \mathrm{hr}$. Glucose constant in all cultures at I\% (w/v). All values are corrected for the amounts of reacting materials precipitated from broth before inoculation.

Fig. 2. The effect of glucose concentration in the culture medium on the concentrations of DNA $(\nabla-\nabla)$, RNA $(\square-\square)$ and protein $(O-O)$ found in the extracellular-2 fraction after incubation for $48 \mathrm{hr}$. $\mathrm{NaCl}$ constant in all cultures at $4.5 \%(\mathrm{w} / \mathrm{v})$. Values not corrected for the amounts of reacting materials precipitated from broth before inoculation.

\section{Growth of the organism and kinetics of excretion of macromolecules}

Preliminary experiments indicated unusual growth characteristics of this organism when it was grown in nutrient broth containing glucose and sodium chloride. To exclude the possibility that this might have been due to a mixed population, nutrient broth, containing $4.5 \%(\mathrm{w} / \mathrm{v}) \mathrm{NaCl}$ and $\mathrm{I} \%(\mathrm{w} / \mathrm{v})$ glucose, was inoculated with a culture grown up from a single colony. At intervals during the incubation, samples of culture were taken, the extinction determined (Fig. 3) and extracellular-2 fraction isolated and analysed (Fig. 4).

The turbidity curve showed several unusual features. After a short lag period of 
about $2 \mathrm{hr}$, followed by $2.5 \mathrm{hr}$ of exponential growth, the turbidity decreased until $8 \mathrm{hr}$. As soon as exponential growth ceased $(4.5 \mathrm{hr})$, the concentration of RNA in the extracellular-2 fraction started to increase. Protein began to accumulate at $4 \mathrm{hr}$, earlier than the nucleic acids and before the cessation of exponential growth, but most of it appeared during the phase of turbidity decrease. From $8 \mathrm{hr}$ to about $\mathrm{I} 5 \mathrm{hr}$ the turbidity remained constant. The cultures, during this time, usually showed visible clumps in an almost clear solution and it was impossible to relate turbidity to colony counts. From $8 \mathrm{hr}$ onwards the concentrations of nucleic acids in the culture supernatant fluid remained constant, whereas the protein concentration decreased, presumably due to the action of excreted proteolytic enzymes. After about $15 \mathrm{hr}$ the turbidity increased again, probably as a consequence of the onset of renewed multiplication. Unexplained variations of this pattern were sometimes observed, mainly in the rate and time of onset of decrease in turbidity (4-7 hr). There was little variation in the amounts of macromolecules which accumulated.

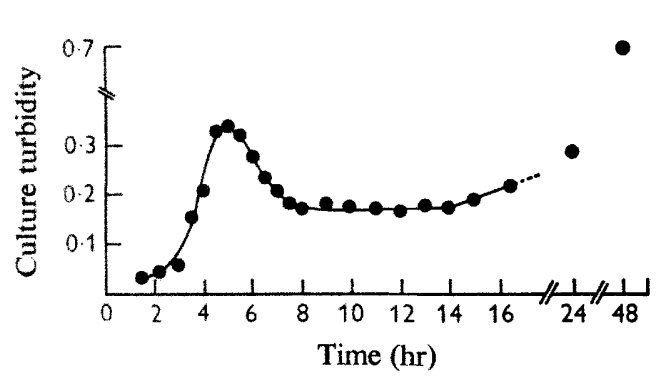

Fig. 3

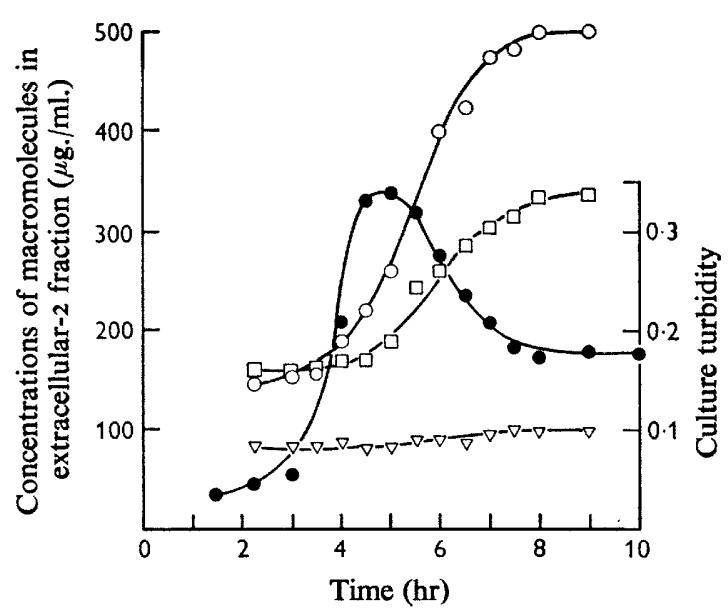

Fig. 4

Fig. 3. Turbidity curve of Staphylococcus aureus JHM growing in nutrient broth, to which $4 \%(\mathrm{w} / \mathrm{v}) \mathrm{NaCl}$ and $\mathrm{I} \%(\mathrm{w} / \mathrm{v})$ glucose had been added.

Fig. 4. The variation, as a function of time, of culture turbidity (--) and levels of DNA $(\nabla-\nabla)$, RNA $(\square-\square)$ and protein $(O-O)$ in the extracellular-2 fraction when $4.5 \%(\mathrm{w} / \mathrm{v})$ $\mathrm{NaCl}$ is present in the culture medium.

A similar growth curve was observed in cultures grown with $6.5 \%(\mathrm{w} / \mathrm{v}) \mathrm{NaCl}$. In this case, however, the initial lag phase was longer and the turbidity decrease less. In cultures grown in $2.5 \%(\mathrm{w} / \mathrm{v}) \mathrm{NaCl}$, the turbidity increased to a higher value than was observed in cultures grown in higher concentrations of $\mathrm{NaCl}$ (Fig. 5). Exponential growth lasted only until $3 \mathrm{hr}$, after which the turbidity increased in a non-exponential manner, reaching a maximum at $6 \mathrm{hr}$, and then fell slowly. Accumulation of extracellular macromolecules began within $4 \mathrm{hr}$ and continued until the turbidity stopped decreasing. The accumulation of DNA showed a similar pattern to that of RNA and protein, but the increase was, as usual, much less.

In the absence of added $\mathrm{NaCl}$ the growth curve was normal. Little or no extracellular nucleic acids were detected (Fig. I), but protein, estimated in this case as 
deoxyribonuclease activity in the extracellular-2 fraction, occurred in measurable amounts in the culture supernatant fluid soon after the onset of growth and increased until the end of growth, after which it decreased slowly.

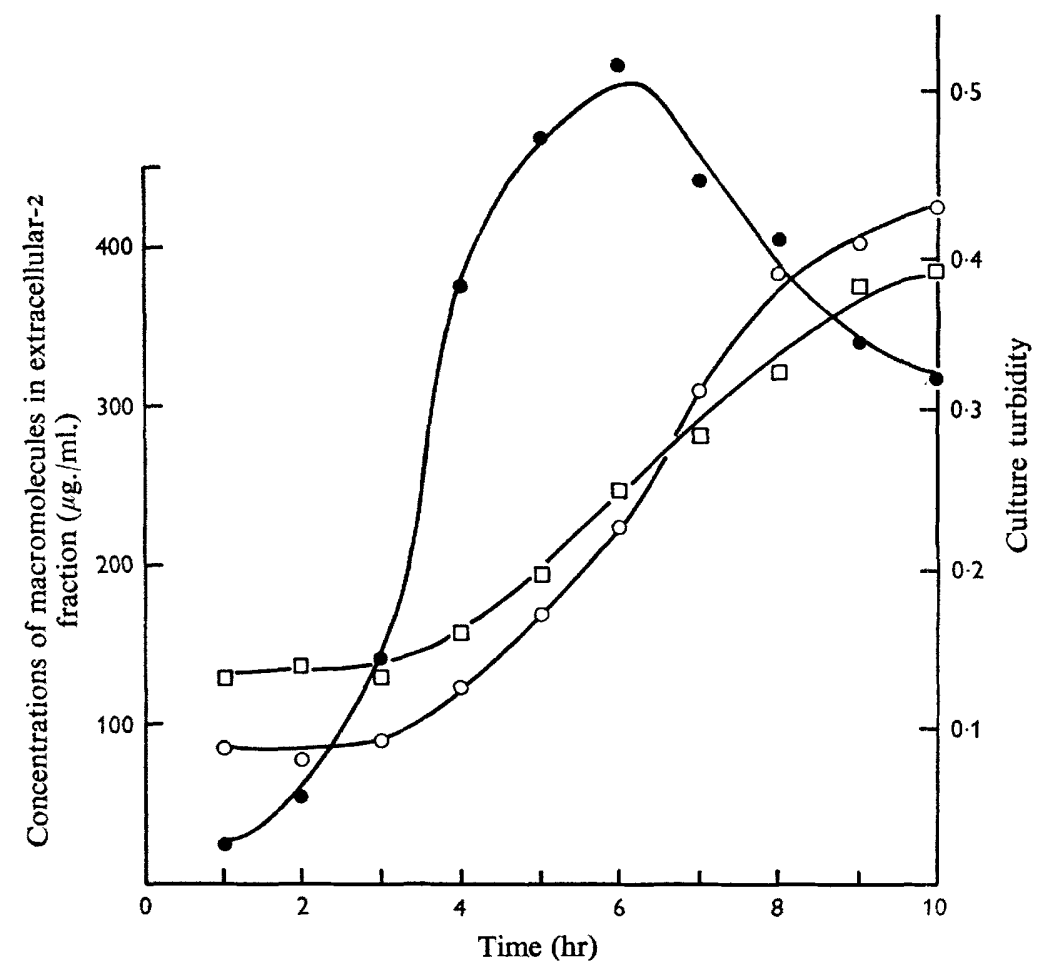

Fig. 5. The variation, as a function of time, of culture turbidity (-๑) and levels of RNA $(\square-\square)$ and protein $(\mathrm{O}-\mathrm{O})$ in the extracellular-2 fraction when $2 \cdot 5 \%(\mathrm{w} / \mathrm{v}) \mathrm{NaCl}$ is present in the culture medium.

\section{Morphology of bacteria grown in the presence of sodium chloride}

Cocci growing in broth with $4.5 \%(\mathrm{w} / \mathrm{v}) \mathrm{NaCl}+\mathrm{I} \%(\mathrm{w} / \mathrm{v})$ glucose were examined at intervals with the aid of an electron microscope. They were compared with normal cocci grown to late exponential phase without added $\mathrm{NaCl}$ but with glucose.

Normal cocci, sometimes seen in pairs (Pl. I, fig. I), were roughly spherical and approximately $1 \mu$ in diameter. Intracytoplasmic membranous structures (mesosomes) were nearly always present. The walls were of constant thickness and the septa were well defined and regular. The addition of $\mathrm{NaCl}$ to this culture medium caused considerable changes in cellular morphology. Organisms harvested after $4.5 \mathrm{hr}$ (at the end of exponential growth, when extracellular materials were beginning to accumulate, Fig. 4) had walls of irregular thickness (Pl. I, figs 2, 3). Septum formation was abnormal, some organisms showing two incipient septa developing at the same time (Pl. I, fig. 2). Also at this stage of growth, the cytoplasmic membrane of some organisms was seen to have contracted away from the cell wall (Pl. I, fig. 3), the space so formed containing membrane-enclosed bodies of various sizes: some of the organisms themselves had irregular shapes. There were some cell structures nearly devoid of cytoplasm, but which 
still contained numerous membrane-enclosed bodies, mostly aligned round the cytoplasmic membrane.

Cultures incubated for $5 \mathrm{hr}$ (to the onset of the turbidity decrease) exhibited further unusual features (Pl. 2; Pl. 3, figs 9-II). There were very few organisms of normal size and shape and those that were observed had exceptionally electron-dense cytoplasm (Pl. 2, fig. 4). The walls were usually characterized by an irregular and somewhat diffuse appearance. There was much debris, often of a fibrous nature. Many organisms had a break in the wall through which cell contents were being lost in various ways. Most common was the emergence of membrane-bounded cytoplasm (Pl. 2, figs 5, 6) but some structures showed leakage of unbounded cytoplasmic material (Pl. 2, fig. 7). Liberation of membranous structures was also seen (Pl. 2, fig. 8). In all cases, extrusion of cell contents occurred through a break in the wall at a point on the plane of division. At this stage many more cocci were seen with the cytoplasmic membrane contracted from the wall ( $\mathrm{Pl}$. 2, figs 4,7 ; $\mathrm{Pl}$. 3, figs 9-II) and with the small membrane-enclosed bodies present between cytoplasmic membrane and wall as in Pl. I, fig. 3; Pl. 3, fig. 9 shows these bodies escaping from the cell through the ruptured septum. Many organisms showed an abnormal feature in having more than one developing septum per cell (Pl. 3, fig. I0). In others, septum formation was complete but an additional 'half' septum was visible in one of the cells (Pl. 3, fig. II). Also, there were cell-wall structures containing various membranous fragments, but no cytoplasm (Pl. 2, fig. 4).

After incubation for $7.5 \mathrm{hr}$ when the turbidity had almost stopped decreasing, much of the material present consisted of fragments of cell-wall, membranes and fibrous debris (Pl. 4, fig. 13). Several structures of abnormal morphology were also seen. Some protoplast-like bodies were observed (Pl. 3, fig. I2; Pl. 4, fig. 13); their diameters varied between 0.8 and $2 \mu$ and some of them contained vacuoles.

After $48 \mathrm{hr}$, when the second growth phase was nearing completion, the cocci were still not normal. They were all roughly spherical but their diameters varied from 0.7 to $\mathrm{I} \cdot 5 \mu$. The walls were, in many cases, remarkably thick and uneven on the inside surface (Pl. 4, fig. 14). In the organisms undergoing division, the septa were often distorted and enlarged. Fragments of wall and other cellular debris were still visible. Another feature was the occurrence of electron-dense particles, about $0 \cdot I \mu$ in diameter, often aligned on the insides of fragments of membrane or surrounded by fibrous material (Pl. 5).

\section{Cell-wall analyses}

Cell walls were prepared from cocci grown for $48 \mathrm{hr}$ in broth containing I \% (w/v) glucose $+4.5 \%(\mathrm{w} / \mathrm{v}) \mathrm{NaCl}$ and were compared with those of normal cocci grown in broth with glucose $(1 \%, \mathrm{w} / \mathrm{v})$ for $24 \mathrm{hr}$. No significant differences in amino acid or amino end-group analyses were found. The molar ratios of glutamic acid, alanine, lysine, glycine, glucosamine and muramic acid were approximately $1: 2: 1: 5: 1 \cdot 2: 1$, similar to those reported for other Staphylococcus strains. The walls had similar phosphorus contents, but those from normal cocci had less carbohydrate $(0 \cdot 72 \%, \mathrm{w} / \mathrm{w})$ and more total hexosamines $(24.2 \%, \mathrm{w} / \mathrm{w})$ than walls from $\mathrm{NaCl}$-grown cocci $(\mathrm{I} \cdot 90$ and $18.4 \%, w / w$, respectively). This suggests that the walls of the cocci grown in $\mathrm{NaCl}+$ glucose medium had a subnormal content of mucopeptide. 


\section{DISCUSSION}

Many types of bacteria accumulate extracellularly macromolecules which would normally be expected to occur only inside the cell. For example, extracellular transforming DNA has been found in cultures of Neisseria meningitidis (Catlin, 1960) and of a pneumococcus (Ottolenghi \& Hotchkiss, 1962). An extracellular material, containing mainly DNA but also some protein and RNA, has been obtained from Micrococcus sodonensis (Campbell, Evans, Perry \& Niven, 196I), and excretion of all three macromolecules by Bacillus subtilis has also been reported (Demain, Burg \& Hendlin, 1965). Slime-layers containing DNA are produced by Micrococcus halodenitrificans and Vibrio costicolus (Smithies \& Gibbons, 1955). The mode of excretion of these macromolecules has not always been obvious, but it has often been assumed that lysis was responsible. In the present investigation on Staphylococcus aureus JHM growing in $\mathrm{NaCl}+$ glucose broth, observations of growth characteristics and cellular morphology showed that lysis took place at the time when extracellular accumulation of macromolecules was occurring. It is thus evident that, for this strain, a gross cellular lysis resulted in apparent excretion of these macromolecules. In view of this intracellular origin, the relatively low concentrations of DNA in the culture supernatant fluid as compared with RNA and protein are understandable, since normal cocci contain less DNA than RNA and protein.

It is probable that not all the protein observed in the culture supernatant fluids originated from lysis. It accumulated in the absence of $\mathrm{NaCl}$ when little or no nucleic acids were detectable (Fig. I) and, in the presence of $\mathrm{NaCl}$, it appeared earlier in the growth cycle than did DNA or RNA (Fig. 4). In cultures containing no added $\mathrm{NaCl}$, part, at least, of the protein was micrococcal nuclease, the concentration of which increased as growth proceeded, and since under these growth conditions electron microscopy revealed no lysis, some other excretion process must have been operating.

Since staphylococci are known to be $\mathrm{NaCl}$-tolerant, the lytic effect of $\mathrm{NaCl}$ needs explanation. $\mathrm{NaCl}$ is known to decrease the rate of hydrolysis of native DNA by extracellular deoxyribonuclease (EC 3. I .4.7; von Hippel \& Felsenfeld, 1964; Dirksen \& Dekker, 1960). This effect probably only aided the accumulation of precipitable nucleic acid in the culture supernatant fluid, but cannot have caused the lysis. The enzyme was still produced in the presence of $\mathrm{NaCl}$, when it could be detected if the culture supernatant fluid was diluted.

Electron microscopy revealed that lysis involved extrusion of intracellular material from a point on the plane of cell division. At this point the developing septum evidently parted before it had been completed, causing rupture and subsequent loss of cell contents. Whether this was due to an interference with cell-wall synthesis, causing a break in the wall at the position where synthesis was proceeding at its maximum rate, is not known. The localized rupture might have resulted from an inhibition by $\mathrm{NaCl}$ of one of the many enzymes involved in cell-wall synthesis; however, no data are available on the $\mathrm{NaCl}$ sensitivity of these enzymes. Another possible effect of $\mathrm{NaCl}$ is the stimulation of an autolytic enzyme associated with the cell wall. Certain lytic enzymes which attack staphylococcal walls are known to require increased ionic concentrations for maximum activity and some of them have acid $\mathrm{pH}$ optima (Schindler \& Schuhardt, I965; Ghuysen \& Strominger, 1963; Mitchell \& Moyle, 1957); while a phage lysin, active against streptococcal walls, is able to operate in $I \cdot I \mathrm{M}-\mathrm{NaCl}$ 
(Barkulis, Smith, Boltralik \& Heymann, 1964). It is possible that $\mathrm{NaCl}$ and the low $\mathrm{pH}$ value resulting from the growth of the staphylococci in glucose may have stimulated one or more lytic enzymes. One such enzyme may serve to separate daughter cocci after septum formation. Other potentially lytic enzymes may open links in the complete mucopeptide structure to enable fresh mucopeptide subunits to be inserted (Weidel \& Pelzer, 1964; Shockman, 1965); their over-activity might result in local wall rupture if synthesis of mucopeptide subunits or their transfer to acceptor sites were not sufficiently rapid to keep pace with degradation. Localization of lytic enzymes is known and is well illustrated by the hemispherical wall fragments produced by autolysis of Staphylococcus aureus (Mitchell \& Moyle, 1957).

The existence, in the lysing cultures, of whole organisms with irregular walls, bizarre shapes and multiple septa suggests that there may have been interference with regulation of cell-wall synthesis and cell division. It is possible that the missing regulators are the mesosomes, since they were never observed in the cytoplasm of cocci grown in $\mathrm{NaCl}+$ glucose broth, but were present in all the normal Staphylococcus aureus JHM organisms. Ryter \& Landman (1964) suggested that mesosomes play a part in regulating cell-wall and septum formation. Mesosomes are known to be lost from the interior of the cytoplasm during protoplast formation and plasmolysis (Fitz-James, 1964; Ryter \& Landman, I964; Weibull, 1965), this loss being associated with the presence of small membrane-bounded structures between the cytoplasmic membrane and the cell wall. Bodies, very similar to these in size and appearance, were found in a similar position in certain organisms of $S$. aureus JHM, and it is probable that these too were derived from mesosomes which had been extruded from the cytoplasm. It is not possible to say whether mesosome loss caused a disturbance in the processes regulating cell division or whether extrusion was the result of some interference with the relationship between wall and membrane.

Whatever the cause or morphological results of lysis of Staphylococcus aureus JHM grown in $\mathrm{NaCl}+$ glucose broth, the fact is that cultures grown up from a single colony eventually emerged from this condition and grew again. Subcultures into fresh $\mathrm{NaCl}+$ glucose broth, made during the long stationary phase before secondary growth began, did not show the usual turbidity decrease. This suggests that the cocci which survived adapted themselves to the conditions and became NaCl-tolerant. Probably the observed $\mathrm{NaCl}$-tolerance of staphylococci always involves such adaptation, but with $S$. aureus JHM other processes take place during the early phase of incubation before adaptation occurs.

It is a pleasure to acknowledge the skilled assistance of Mrs P. Riches in this work. We also thank Dr M. Vesk for the electron micrographs, and $\mathrm{Mr}$ J. Shaw for amino acid analyses.

\section{REFERENCES}

AleXander, M., Heppel, L. A. \& Hurwttz, J. (196I). The purification and properties of micrococcal nuclease. J. biol. Chem. 236, 3014 .

AllsOP, J. \& WORK, E. (1963). Cell walls of Propionibacterium species: fractionation and composition. Biochem. J. 87, 512.

Anfinsen, C. B., Taniuchi, H., Heins, J. N. \& Suriano, J. R. (I965). Studies on an extracellular nuclease of Staphylococcus aureus. Science, N.Y. 150, 368.

Barkulis, S. S., Smith, C., Boltralik, J. J. \& HeymanN, H. (1964). Structure of streptococcal cell walls. J. biol. Chem. $239,4027$. 
BURTON, K. (1956). A study of the conditions and mechanism of the diphenylamine reaction for the colorimetric estimation of deoxyribonucleic acid. Biochem. J. 62, 315.

Camprell, J. N., Evans, J. B., Perry, J. J. \& Niven, C. F. (196i). An extracellular material elaborated by Micrococcus sodonensis. J. Bact. 82, 828 .

CATLIN, B. W. (1960). Transformation of Neisseria meningitidis by deoxyribonucleates from cells and from culture slime. J. Bact. 79, 579.

Catuin, B. W. \& Cunningham, L. S. (1958). Studies of extracellular and intracellular bacterial deoxyribonucleic acids. J. gen. Microbiol. 19, 522.

Cunningham, L., Catlin, B. W. \& Privat de Garilhe, M. (1956) A deoxyribonuclease of Micrococcus pyogenes. J. Am. chem. Soc. 78, 4642.

Demain, A. L., Burg, R. W. \& Hendlin, D. (1965). Excretion and degradation of ribonucleic acid by Bacillus subtilis. J. Bact. 89, 640 .

DIRKSEN, M. L. \& DeKKeR, C. A. (1960). Micrococcal nuclease: consideration of its mode of action. Biochem. biophys. Res. Commun. 2, 147.

FITZ-JAMES, P. (1964). Fate of the mesosomes of Bacillus megaterium during protoplasting. J. Bact. 87, I483.

GHUYSEN, J. M. \& STROMINGer, J. L. (1963). Structure of the cell wall of Staphylococcus aureus, strain COPENHAGEN. 1. Preparation of fragments by enzymic hydrolysis. Biochemistry 2, II Io.

voN HiPPEL, P. H. \& FeLSENFELD, G. (1964). Micrococcal nuclease as a probe of DNA conformation. Biochemistry 3, 27.

Lowry, O. H., Rosebrough, N. J., Farr, A. L. \& Randall, R. J. (195I). Protein measurement with the Folin phenol reagent. J. biol. Chem. 193, 265.

LUFT, J. H. (196I). Improvements in epoxy resin embedding methods. J. biophys. biochem. Cytol. 9, 409.

Mitchell, P. \& MoYLe, J. (1957). Autolytic release and osmotic properties of 'protoplasts' from Staphylococcus aureus. J. gen. Microbiol. 16, 184.

MORSE, M. L. \& CARTER, C. E. (1949). The synthesis of nucleic acids in cultures of Escherichia coli, strains $B$ and $\mathrm{B} / \mathrm{R}$. J. Bact. 58, 317.

OtTOLENGHI, E. \& HotchKiss, R. D. (1962). Release of genetic transforming agent from pneumococcal cultures during growth and disintegration. J. exp. Med. rr6, 491.

REDDI, K. K. (1961). Action of micrococcal phosphodiesterase on polyribonucleotides termined by guanylic acid. Biochim. biophys. Acta 47, 47.

RYTER, A. \& LANDMAN, O. E. (1964). Electron microscope study of the relationship between mesosome loss and the stable L-state (or protoplast state) in Bacillus subtilis. J. Bact. 88, 457.

Schindler, C. A. \& Schumardt, V. T. (1965). Purification and properties of lysostaphin-a lytic agent for Staphylococcus aureus. Biochim. biophys. Acta 97, 242.

Shockman, G. D. (1965). Unbalanced cell-wall synthesis: autolysis and cell-wall thickening. Bact. Rev. 29, 345.

SMItHIEs, W. R. \& GibBons, N. E. (1955). The deoxyribose nucleic acid slime layer of some halophilic bacteria. Can. J. Microbiol. 1, 6 I4.

Werbull, C. (1965) Plasmolysis in Bacillus megaterium. J. Bact. 89, I 5 I.

WEIDEL, W. \& PELZER, H. (I964). Bagshaped macromolecules-a new outlook on bacterial cell walls. Adv. Enzymol. 26, 193.

\section{EXPLANATION OF PLATES}

Plate I

Fig. I. Section of a normal staphylococcus grown in the presence of glucose but in the absence of added $\mathrm{NaCl}$ (i.e. only $0.5 \% \mathrm{NaCl}$ ). Mesosomes are evident and the wall and septum are well defined. $\times 80,000$.

Figs. 2, 3. Staphylococci grown for $4.5 \mathrm{hr}$ in the presence of $\mathrm{NaCl}(4.5 \%)+$ glucose. Cell walls are of irregular thickness and septum formation is abnormal, there being two incipient septa per cell in some cases (fig. 2). In some organisms (fig. 3 ) the cytoplasmic membrane has contracted away from the wall and membrane-enclosed bodies are visible in the spaces formed. $\times 40,000$.

Plate 2

Staphylococci grown for $5 \mathrm{hr}$ in the presence of $\mathrm{NaCl}+$ glucose.

Fig. 4. Field showing organisms with very electron-dense cytoplasm, wall structures containing membrane fragments but no cytoplasm and organisms with contracted cytoplasm. Note the appearance of fibrous debris. $\times 40,000$. 
Journal of General Microbiology, Vol. 49, No. 1

Plate 1
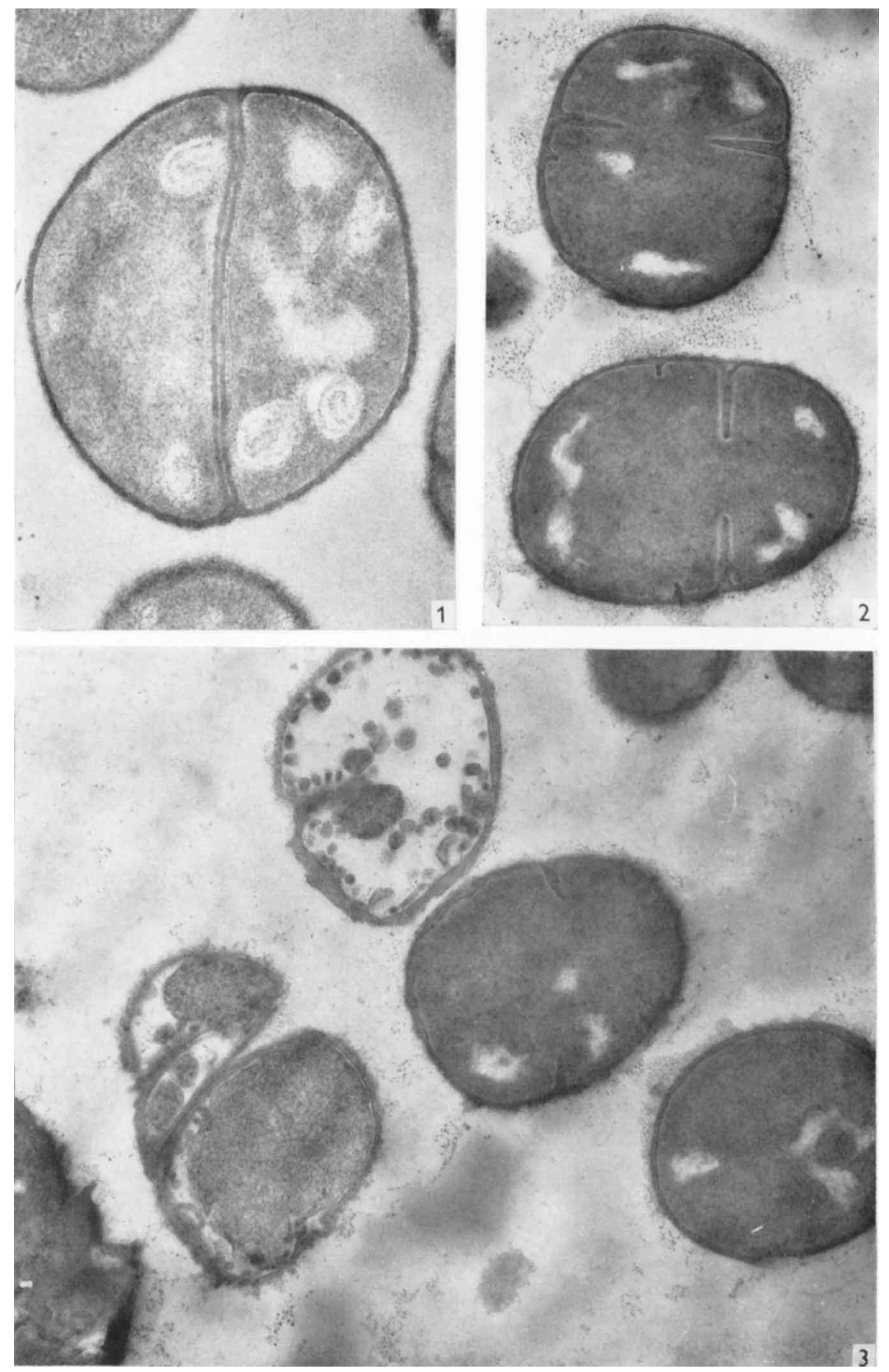


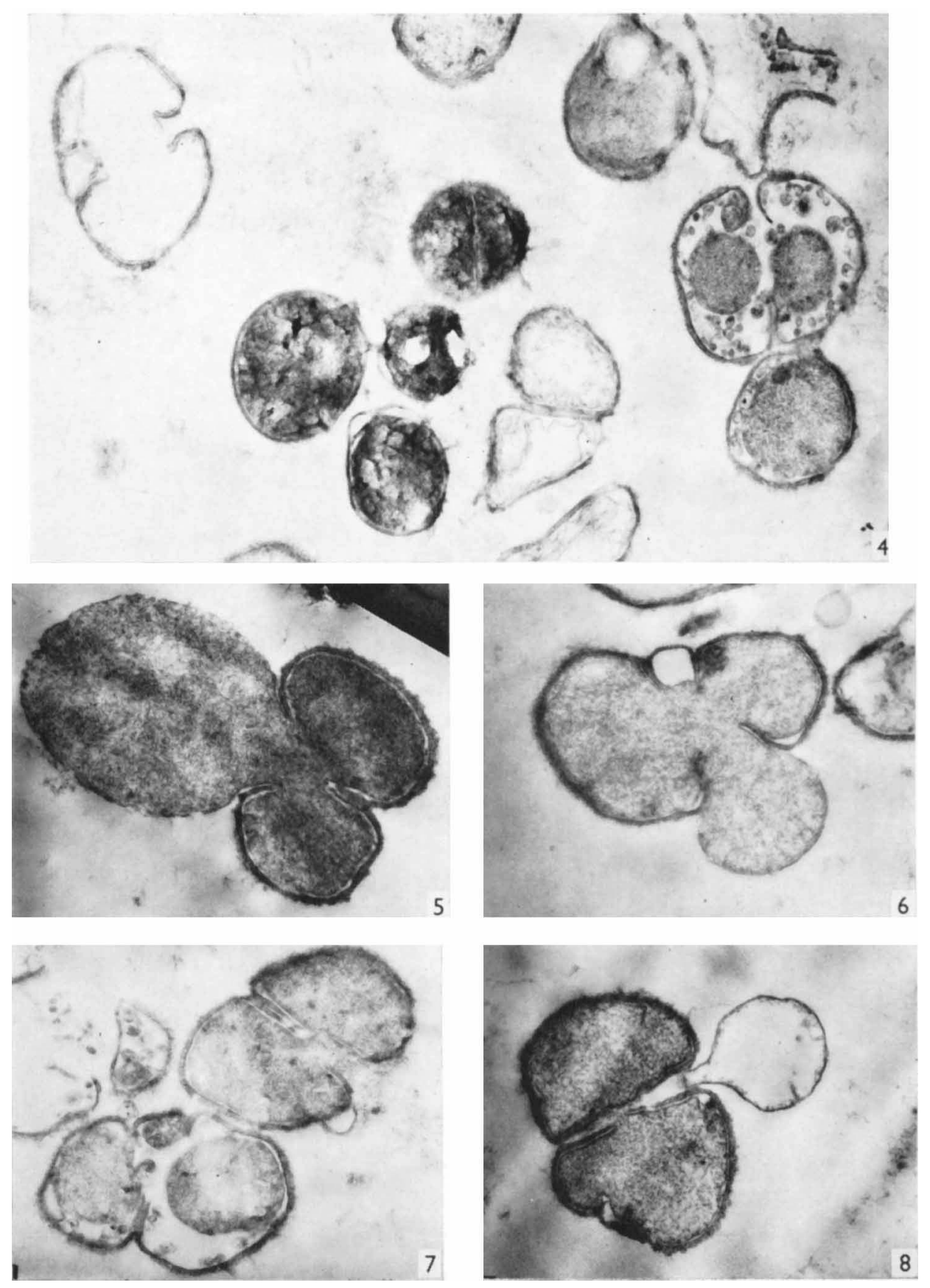



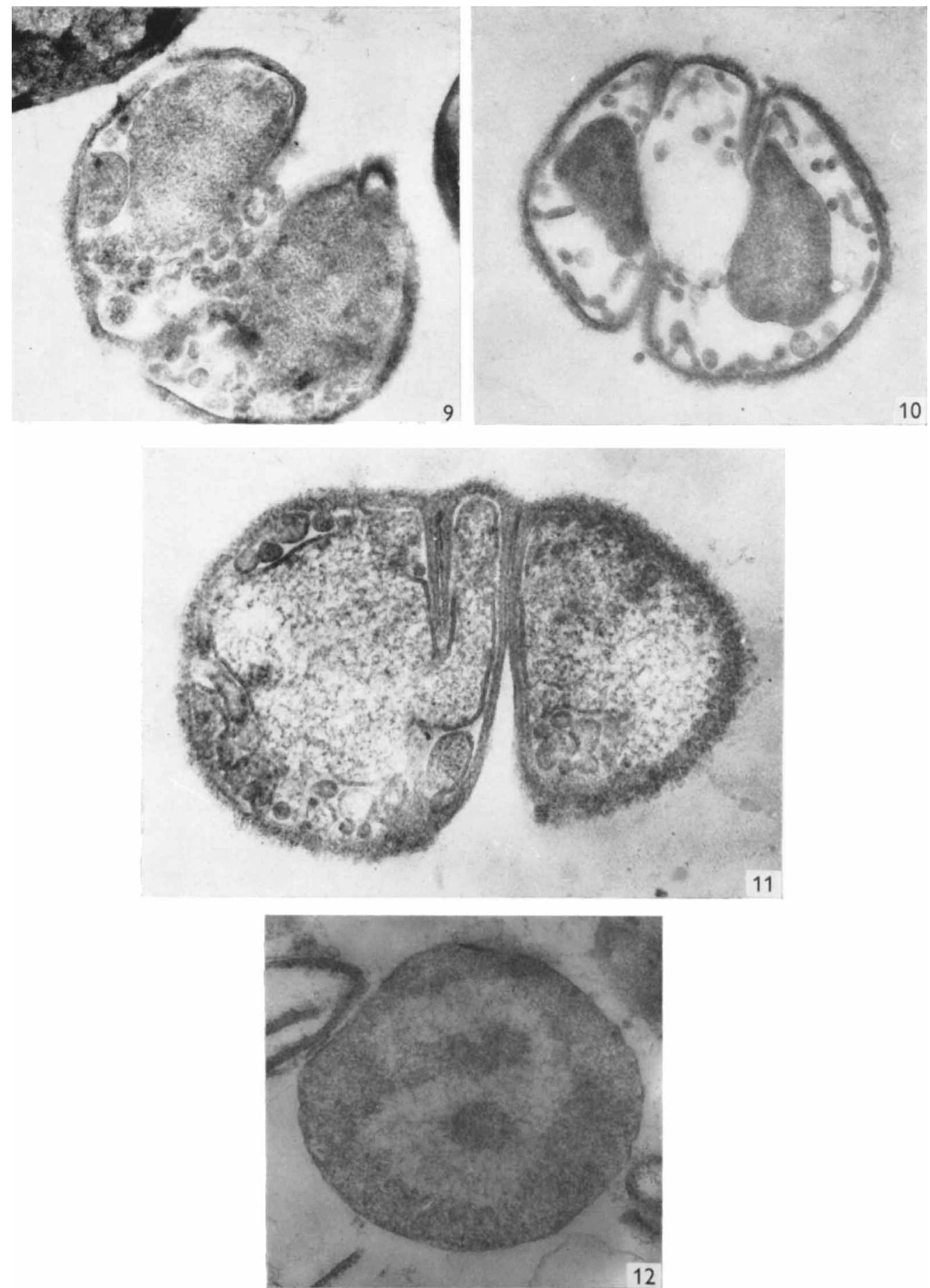
Journal of General Microbiology, Vol. 49, No. 1

Plate 4
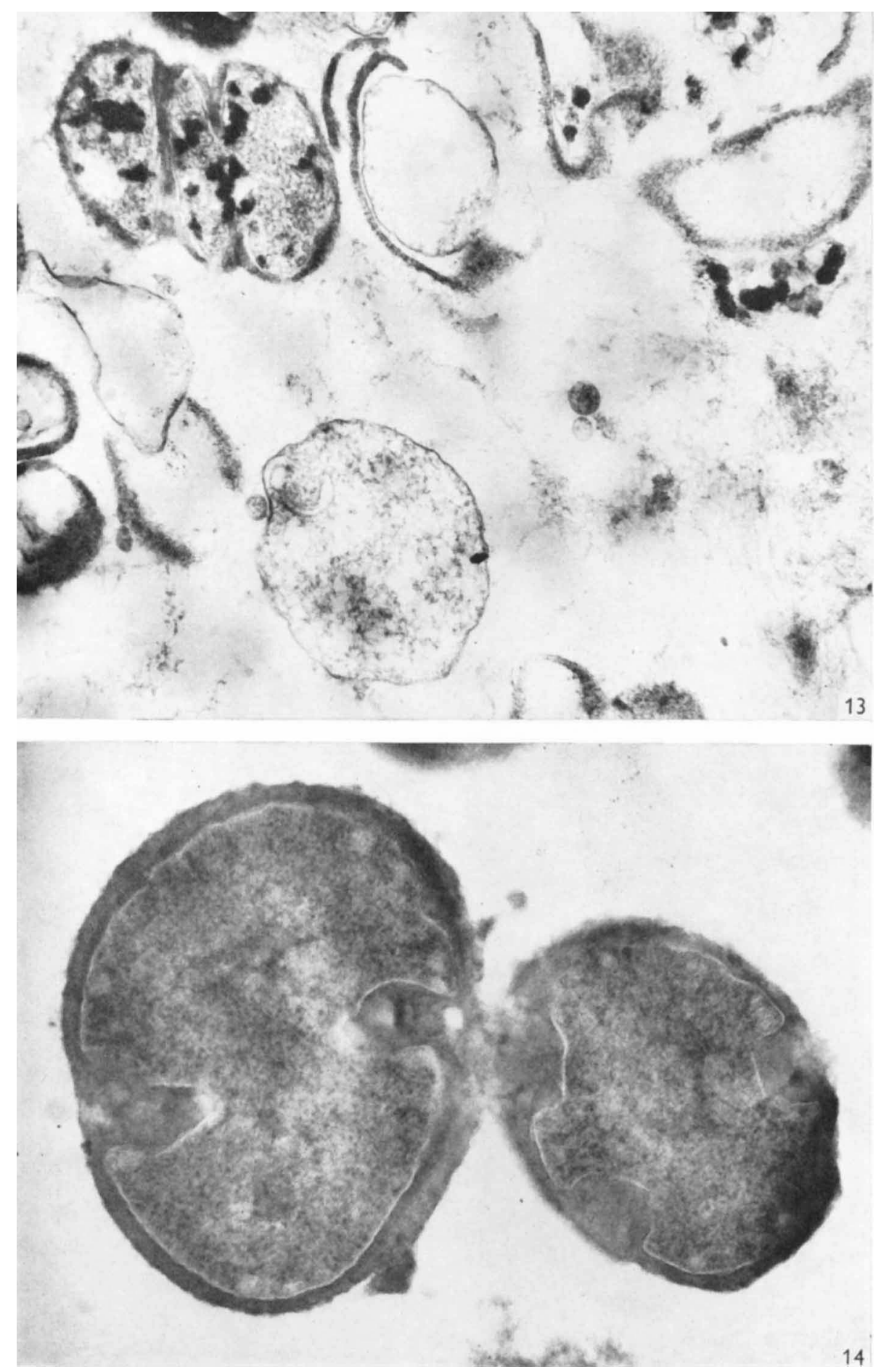

R. E. CRIPPS AND E. WORK 


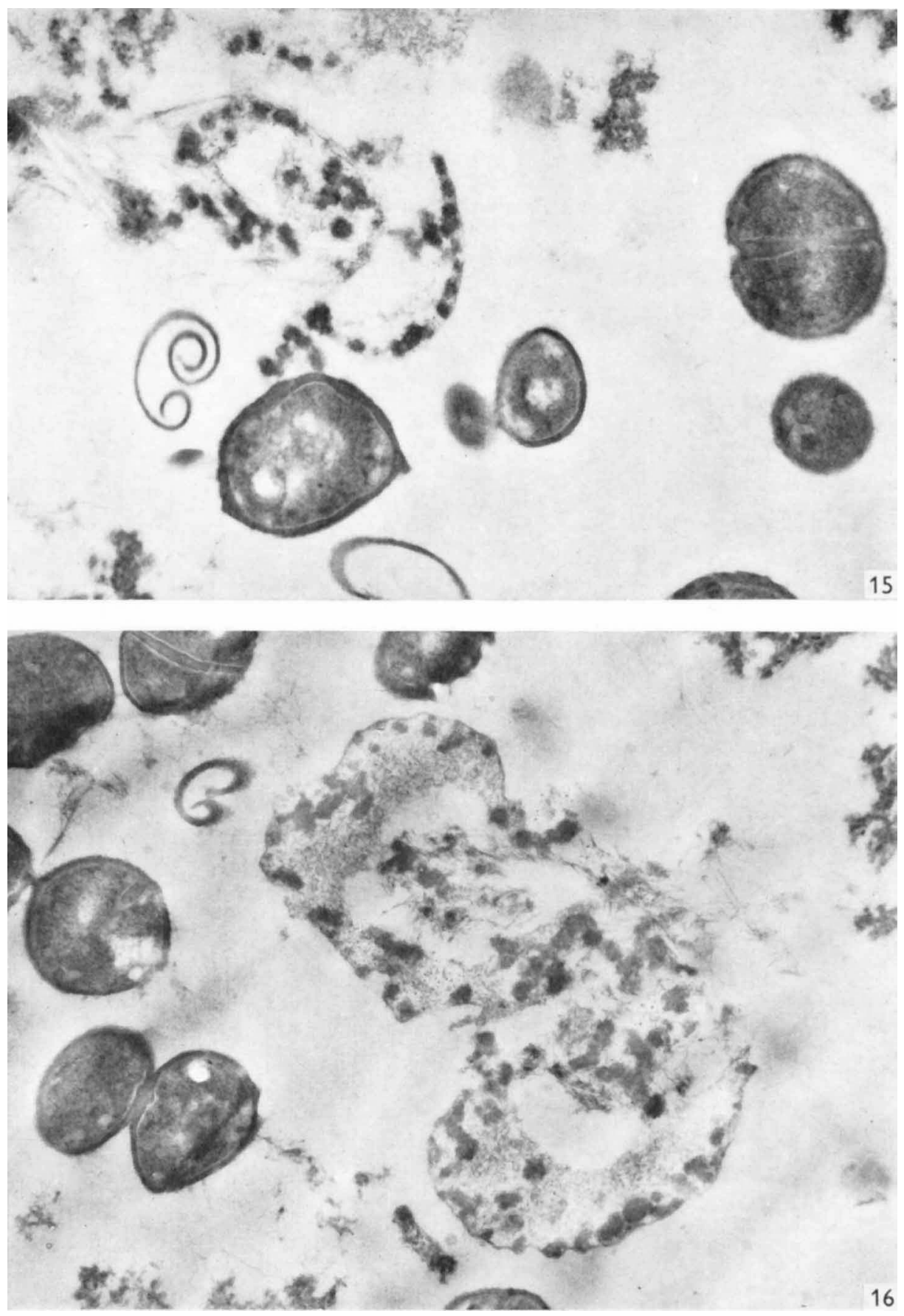


Figs. 5, 6. The cell contents are being extruded enclosed in the cytoplasmic membrane. The walls have a rough appearance and are irregular in shape. $\times 40,000$.

Fig. 7. Cell contents are being extruded, unbounded by a membrane. Also, contraction of membrane from the wall is apparent. $\times 40,000$.

Fig. 8. Liberation of a membranous structure. $\times 40,000$.

Plate 3

Figs. 9, 10, 11 . Staphylococci grown for $5 \mathrm{hr}$ in the presence of $\mathrm{NaCl}+$ glucose.

Fig. 9. Organism with broken wall through which the membrane-enclosed bodies are escaping. $\times 80,000$.

Fig. 10. Organism, of abnormal shape, having more than one septum and a contracted cytoplasm. $\times 80,000$.

Fig. 11. Pair of organisms, one of which contains a 'half' septum. In both structures the membrane has contracted from the wall and membrane-enclosed bodies appear in the spaces formed. $\times 80,000$.

Fig. 12. A large protoplast-like body, $2 \mu$ in diameter, produced after $7.5 \mathrm{hr}$ incubation in $\mathrm{NaCl}+$ glucose broth. Wall fragments are also visible. $\times 40,000$.

\section{Plate 4}

Fig. 13. Field showing abnormal organisms, protoplast-like bodies, fragments of walls and membranes and much fibrous debris after $7.5 \mathrm{hr}$ incubation in $\mathrm{NaCl}+$ glucose broth. $\times 40,000$.

Fig. 14. Cocci, after $48 \mathrm{hr}$ incubation in $\mathrm{NaCl}+$ glucose broth, having very thick walls which are very uneven on the inside surface. $\times 80,000$.

$$
\text { Plate } 5
$$

Figs. 15, 16. After $48 \mathrm{hr}$ incubation; fields showing bodies with, in most cases, thick and uneven walls; the septa of dividing organisms often distorted and enlarged; wall fragments visible, also dense particles aligned on membranous structures or surrounded by debris of a fibrous nature. $\times 40,000$. 